\title{
THE FALLACY OF ORGANIC AND CONVENTIONAL FRUIT AND VEGETABLE PRICES IN THE METROPOLITAN REGION OF CAMPINAS, SÃO PAULO, BRAZIL
}

\author{
Maria Aico Watanabe, Lucimar Santiago de Abreu, Alfredo José Barreto Luiz
}

Embrapa Meio Ambiente, Caixa Postal 69, 13820-000 Jaguariúna, SP, Brazil.

Corresponding author e-mail: aico.watanabe@embrapa.br

Citation: Watanabe, M.A., de Abreu, L.S., and Luiz, A.J.B.. 2020. The fallacy of organic and conventional fruit and vegetable prices in the metropolitan region of campinas, São Paulo, Brazil. J. Asian Rur. Stud. 4(1): 1-22

\begin{abstract}
There is a popular myth or fallacy based on the idea that organic fruits and vegetables are always more expensive than conventional products. To assess whether this statement is true, a qualitative and quantitative research was conducted between September and December 2017, involving four supermarkets and seven outdoor markets, located in Campinas, in the State of São Paulo, Brazil. This statement was confirmed for the research conducted in supermarkets, but not for outdoor markets, where some organic products are cheaper than conventional ones. In fact, supermarkets sell organic products at higher prices and, normally, only the upper middle class has access to the products, but the consumer will have the option to buy conventional products at lower prices. Conventional supermarket products serve a larger number of consumers, including those with lower incomes. Most outdoor market traders are farmers who sell their own harvested products. Thus, these producers set their own prices, which are more attractive to the consumer; however, prices may vary. Due to price differences between supermarkets and free markets, consumers in general, and especially low-income consumers, obtain affordable, healthy, fresh and seasonal products, especially in outdoor markets. It is concluded that the best option for the low-income consumer is to buy organic products in openair markets, since in these locations' prices are generally cheaper, the products are healthier and fresher. The consumer also has access to diverse "seasonal" products, which are even cheaper and fresher are offered throughout the year, thus allowing the consumer to have a healthy and diverse diet throughout the year.
\end{abstract}

Keywords: Organic produce; supermarket; outdoor markets; price establishment policy; purchasing strategies

\section{Introduction}

The scientific discoveries of the last decades about the means to keep good health and the injuries on the health provoked by consumption of pesticide-residues contaminated foods is leading the population to be increasingly concerned with health problems. Among other decisions, the people are looking for the consumption of organic pesticide-free foods (Guivant, 2003; Noronha, 2008; Dunn et al., 2014. Johansson et al., 2014). But these produces are usually considered expensive and there are hindrances with respect to their availability all over the year, their quality, quantity 
and diversity (Holloway and Kneafsey, 2000; Sanderson et al., 2005; Souza, 2005; Potrich et al., 2013

Conventional produce are contaminated by heavy metals $(\mathrm{Hg}, \mathrm{Cd}, \mathrm{Pb}, \mathrm{Mn}, \mathrm{Ni}$ and Co) (Woese et al., 1997; Mansur et al., 2009); pesticide residues (Noronha, 2008; Smith-Spangler et al., 2012; Dunn et al., 2014) and chemical fertilizer residues (Dunn et al., 2014). Organic produce are produced without chemical pesticide sprayings, using organic fertilizers (AAO, s. d.) and are healthier than conventional produce (Guivant, 2003; Smith-Spangler et al., 2012; Johansson et al., 2014), present higher healthful minerals ( $\mathrm{Fe}, \mathrm{Zn}, \mathrm{Mg}$ and $\mathrm{K}$ ) carotenoids, vitamins $\mathrm{B}$ and $\mathrm{C}$, phenolic compounds with higher antioxidant properties (Carys-Veyrat, et al.,' 2004; Stracke et al., 2009; Cardoso et al., 2011; Akbaba et al., 2012; Smith-Spangler et al., 2012; Hallmann and Rembialkowska, 2012; Johansson et al., 2014). The nutritional quality of organic produce can be furtherly enhanced if they are harvested in "in season" time, because vitamin $\mathrm{A}, \mathrm{B}$ and $\mathrm{C}$ contents are influenced by temperature and luminous intensity variation alongside the months of the year (Gautier et al., 2008; Kader et al., 2014).

As the time elapses from harvest to consumption time, the nutritional quality of the produce deteriorates (Holloway and Kneafsey, 2000). Produce grown locally and sold soon after harvest are then fresher and healthier and these produce are sold in outdoor markets, whereas produce sold in supermarkets travel long distance and spend long time before reaching the consumers hands (Archer, 2003. Sanderson et al., 2005; Morel et al., 2015). Some authors state that in Brazil the supermarkets are the preferred vending channels to purchase produce, because the customers prefer to find all they need in one place and where they can choose the produce directly from the shelves (Souza, 2005).

Besides purchasing cheaper, fresher and healthier products at outdoor markets, in these commercial channels the consumers can know the producers of the foods they are purchasing, because the farmer markets stand owners are farmers who produce the produce they are selling on their stands (Holloway and Kneafsey, 2000; Sanderson et al., 2005; Jolly et al., 2005).

Purchasing organic produce from outdoor markets, the consumers are helping the smallholder farmers to earn money and rural exodus is discouraged. This is the benefit of outdoor market establishment to smallholder farmers (Camarando and Abramovay, 1999; Ferrari et al., 2004; Castro, 2004). The establishment of a farmer market in a district benefits the community specially the low income community, providing its food security, contributing to agricultural diversity and keeping the environment ecologically clean (Jolly et al., 2005).

The WHO/FAO (2004) recommends a daily fruit and vegetable intake of at least 400 g or 5 servings. According to WHO/FAO (2004) and FAO (2015) adequate fruit and vegetable daily intake helps to prevent and reduce risks of some types of cancer, cardiovascular diseases (CVD), stroke (CVA), type 2 diabetes and obesity. In this paper, WHO/FAO (2004) recommend as goals for countries or communities to increase fruit and vegetable year round production, its quality, availability and affordability. For consumers $\mathrm{WHO} / \mathrm{FAO}$ recommend to increase the amount of fruit and vegetable intake at least until reaching the recommended daily intake. 
In São Paulo, Brazil $35 \%$ of the low income elderly does not have any fruit or vegetable at all in their daily diet; $45.2 \%$ fruit and vegetable daily intake is less than the recommended; only $20.6 \%$ of women and $14.8 \%$ of men have fruit and vegetable daily intake above the recommended level (Viebig et al., 2009). In Piracicaba, São Paulo State, Brazil, $47 \%$ of the low income adults do not have the recommended fruit and vegetable daily intake (Bigaran and Salgado, 2017).

The central issue in this research is to investigate where we find the prices of organic products most affordable to consumers in general, and particularly low-income consumers, to understand how they can obtain healthy, fresh, diverse, seasonal and at the same time cheap food in relation to the overall cost practiced, and it is undoubtedly a profoundly challenging issue.

This paper had as objectives: 1. To establish comparison between the produce prices differences between supermarkets and outdoor markets; 2. Contribute to the construction of strategies for the purchase of organic products for consumers in general, and particularly for low-income consumers. to conduct them to outdoor markets because in these commercial channels they can find cheaper, healthier, fresher and seasonal produce, instead of supermarkets because in these places organic produce although easily available directly from the shelves, they are not affordable for them besides being less fresh and less healthy.

\section{Material and Methods}

Campinas is the second largest city of São Paulo State, which is located in the Southeast Brazil. So, a metropolitan region. The city is well served by outdoor markets and supermarkets, which offer both organic and conventional fruits and vegetables. From September to December 2017, an investigation was conducted involving seven outdoor markets located in the districts of Cambuí, Jardim Flamboyant, Taquaral and Barão Geraldo, four supermarkets the Supermercado Pão de Açúcar located in Cambuí, Hipermercado Carrefour located in Jardim Flamboyant, Supermercdo Dalben located in Taquaral and another Supermercado Pão de Açúcar located in Barão Geraldo.

The group of producers who participate in the organic free markets belong to the Association of Natural Agriculture of Campinas (ANC) (https://anc.org.br/mapa/). ANC was created in 1991, composed of eight members, most of whom were militants of the social movement of alternative agriculture and who today call themselves militants of the agroecological movement and the organic movement. According to the founding members, whose farmers still sell their products in free markets, the ANC emerges from the growing demand for an alternative marketing space to retail chains. When created, the members were concerned with safeguarding the quality of the products offered by the ANC. Currently, it has 127 producers, in addition to technicians, researchers and consumers participating in the association.

The supply equipment were selected taking into consideration the higher number of visiting consumers, the social recognition - the most traditional and the oldest and which were offering higher diversity and volume of produce. 
Data collection choice - Data collection was conducted from September to December 2017 but any other time of the year could be selected for data collection. Thus, this was a casual choice.

Data collection time is associated to research objectives: To make a comparison of the same produce sold in two supply equipment - supermarkets and outdoor markets. Therefore, in the data collection were selected the same produce for price comparative analysis in supermarkets as well as in organic outdoor markets and conventional outdoor markets. Part of the collected data referring to survey made in Barão Geraldo district was already presented in an event and published (Watanabe et al., 2018)

The outdoor markets stands owners were interviewed with respect to the prices of their produce and if they were the producers of the fruits and vegetables that were selling. The supermarkets managers were also interviewed with respect to from where or from whom they purchase the produce that they are commercializing.

Their responses were tabulated and the prices differences were estimated. The differences between the prices were calculated according to the formula:

$$
\left(\frac{A}{B} \times 100\right)-100
$$

Where: $\mathrm{A}$ and $\mathrm{B}$ are the pair of prices in comparison and $\mathrm{A}>\mathrm{B}$.

Organic produce prices of each supermarket were compared with conventional produce prices to evaluation of prices differences within the same supermarket.

Organic produce prices of different supermarkets were also compared to evaluation of organic produce prices differences between supermarkets.

Supermarkets organic produce prices were compared with the outdoor market organic produce to evaluation of price differences between supermarkets and outdoor markets.

The prices differences were classified according to the magnitude in the following scale: $0=$ No difference between the pair of prices

$0<\% \leq 100=$ Differences in the interval higher than 0 and up to $100 \%$

$100<\% \leq 200=$ Differences in the interval higher than 100 and up to $200 \%$

$200=$ Difference above $200 \%$

The supply equipment's supermarkets as well as outdoor markets were visited only once. The produce' prices were collected through interviews with supermarkets managers and stand owner at outdoor markets or through observations. In the supermarkets as the prices of each produce was collected only once, it was not possible to calculate means or medians. In each outdoor markets several stands were visited, and were calculated mean price of each produce.

It was included in the research only the stand owners who were also farmers. In organic outdoor market, the majority of the stand owners are also small farmers who commercialize their own harvests directly at the outdoor markets. The stand owner farmers of our research are organic farmers established in East Region of São Paulo State and members of the Association de Agriculture Natural de Campinas (ANC). 
(Natural Agriculture Association of Campinas).

The majority of the conventional stand owners are resellers who purchase the produce at CEASA - Supply Center that commercialize produce on wholesale basis. The CEASA boxes owners purchase the conventional produce from the farmers and sell them to outdoor market stand owners.

MAPS - To facilitate the localization of the data collection points, following maps were constructed:

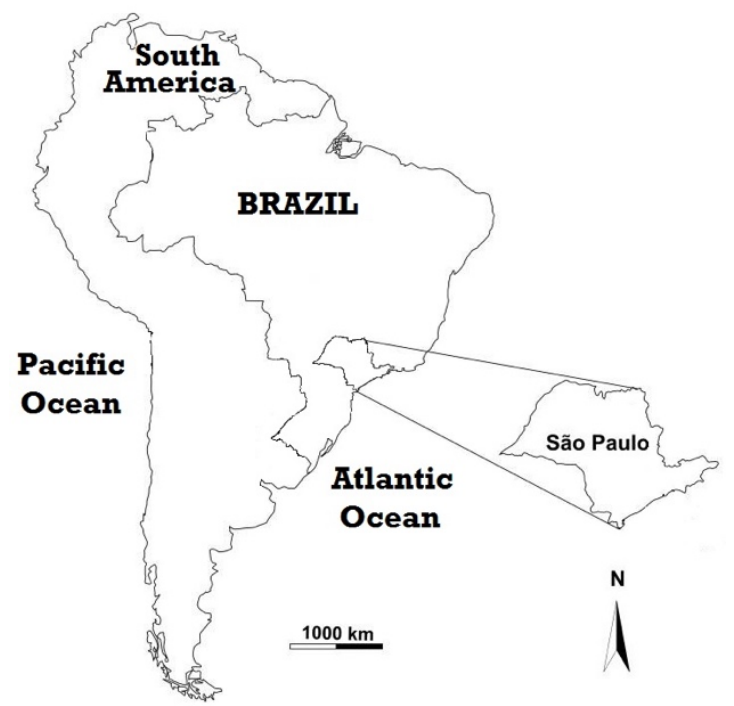

Figure 1. South America map, with the localization of Brazil and inside this the São Paulo State

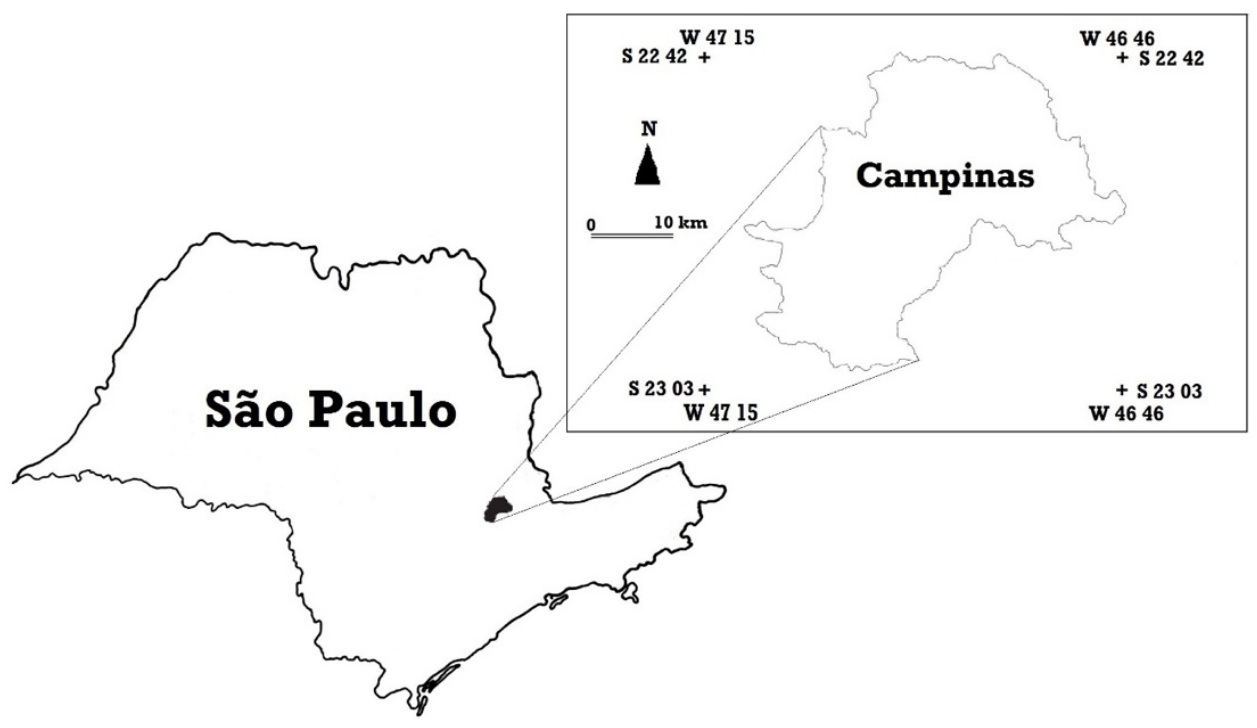

Figure 2. São Paulo State map, with the localization of Campinas City 


\section{Campinas}

7

2

1

$4 \quad 3$

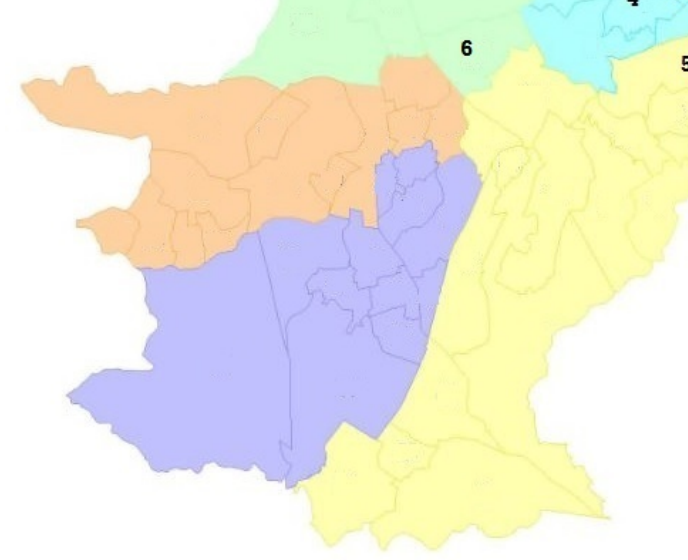

5

1 - Jardim Flamboyant

2 - Taquaral

3 - Bosque dos Jaquitibás

4 - Cambuí

5 - Parque Ecológico

6 - Jardim Guanabara

7 - Barão Geraldo

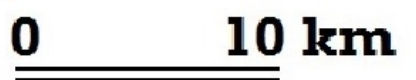

Figure 3. Campinas map, with the localization of the districts where data collection were conducted: Barão Geraldo, Taquaral, Cambuí, Jardim Flamboyant, Parque Ecológico, Jardim Guanabara and Bosque dos Jequitibás.

For complementation of our collected data specialized literature reading were also included in the study. The purchasing strategies were constructed and justified according to literature classification of fresh, healthy and seasonal produce.

\section{Results}

\subsection{Cambuí (Table 1)}

In Cambuí district data collection was conducted in the Supermercado Pão de Açúcar (Organic and conventional produce), Feira Orgânica do Parque Ecológico (organic produce), Feira Convencional do Centro de Convivência (conventional produce) and Feira Convencional da Rua Maria Monteiro (conventional produce).

Table 1 lists the 14 produce offered in the five options (place of commercialization and method of production - organic or conventional). We can see that $11(78.6 \%)$ out of 14 organic produce of Pão de Açúcar (SPAOC) were the most expensive. For conventional produce offered by this supermarket (SPACC) 10 (71.4\%) out of 14 were the cheapest.

In the Feira Orgânica do Parque Ecológico (FPE) only 1 (7.1\%) out of 14 were the most expensive which was the pear "Williams" sold at R $\$ 28.00 / \mathrm{kg}$. 
In the Feira Convencional do Centro de Convivência (FCB) only $2(14.3 \%)$ out of 14 were the most expensive which were the eggplant sold at $\mathrm{R} \$ 11.95 / \mathrm{kg}$ and the pumpkin "Kabotchá" sold at R \$9.40/kg

In the Feira Convencional da Rua Maria Monteiro (FMM) it was found $3(35.7 \%)$ products out of 14 that were the cheapest.

Prices in Reais (Brazilian Currency)

In Cambuí, it was found 161 produce, being 86 vegetables and 75 fruits, which 14 produce are offered in five options.

Table 1. Produces (vegetables and fruits) sold at one supermarket and three outdoor markets in Cambuí, Campinas, SP, Brazil

$\begin{array}{lllllll}\text { Produce } & \text { Unity } & \text { SPAO } & \text { SPAC } & \text { FPE } & \text { FCB } & \text { FMM } \\ & & & & & & \\ \text { Banana "Nanica" } & \mathrm{kg} & 13.78 & 4.99 & 7.00 & 4.90 & 3.90 \\ \text { Banana "Prata" } & \mathrm{kg} & 16.38 & 5.99 & 7.00 & 6.90 & 3.90 \\ \text { Beet root } & \mathrm{kg} & 19.58 & 3.75 & 8.00 & 7.00 & 8.90 \\ \text { Broccoli "Ninja" } & \mathrm{kg} & 10.39 & 5.99 & 8.50 & 8.40 & 5.50 \\ \text { Carrot } & \mathrm{kg} & 9.09 & 2.99 & 6.50 & 7.85 & 4.80 \\ \text { Chayote } & \mathrm{kg} & 16.58 & 1.99 & 7.00 & 8.35 & 3.50 \\ \text { Collard "But er" } & \text { bunch } & 7.39 & 3.29 & 4.33 & 5.50 & 4.95 \\ \text { Eggplant } & \mathrm{kg} & 9.39 & 18.78 & 8.00 & 11.95 & 7.35 \\ \text { Let tice "Crespa" } & \text { unity } & 4.75 & 2.13 & 3.29 & 4.50 & 3.45 \\ \text { Parsley and green onion } & \text { bunch } & 5.59 & 5.59 & 3.00 & 3.00 & 2.75 \\ \text { Pear "Williams" } & \mathrm{kg} & 23.98 & 23.98 & 28.00 & 12.00 & 14.00 \\ \text { Pumpkin "Kabotchá" } & \mathrm{kg} & 7.99 & 2.76 & 7.50 & 9.40 & 5.30 \\ \text { Sweet potato } & \mathrm{kg} & 8.99 & 3.59 & 8.17 & 8.35 & 7.80 \\ \text { Zucchini } & \mathrm{kg} & 19.38 & 3.99 & 10.33 & 8.80 & 7.35\end{array}$

SPAO = Supermercado Pão de Açúcar - organic produce

SPAC - Supermercado Pão de Açúcar - convent bnal produce

FPE - Feira Orgânica do Parque Ecológico - organic outdoor market

FCB - Feira Convencional do Centro de Convivência - convent bnal outdoor market

FMM - Feira convencional da Rua Maria Monteiro - convent bnal outdoor market

SPAO most expensive $=11 / 14=78.6 \%$

FPE most expensive $=1 / 14=7.1 \%$

$\mathrm{FCB}$ most expensive $=2 / 14=14.3 \%$

SPAC cheapest $\quad=10 / 14=71.4 \%$

FMM cheapest $\quad=5 / 14-35.7 \%$ 


\subsection{Jardim Flamboyant (Table 2)}

In Jardim Flamboyant data collection was conducted at Hipermercado Carrefour and Feira Convencional do Jardim Flamboyant.

$19(95.0 \%)$ out of 20 organic produce offered by Hipermercado Carrefour (HCRO) were the most expensive; $17(85.0 \%)$ out of 20 conventional produce of the same supermarket (HCRC) were the cheapest; 1 (11.1\%) out of 20 conventional produce offered by Feira Convencional do Jardim Flamboyantr (FFB) were the cheapest.

Prices in Reais (Brazilian Currency)

20 produce were offered in all 3 options. In Jardim Flamboyant it was found 65 vegetables and 45 fruits summing up 110 produce.

Table 2. Produces (vegetables and fruits) sold at one supermarket and one outdoor market in Jardim Flamboyant, Campinas, SP, Brazil

$\begin{array}{lllll}\text { Produce } & \text { Unity } & \text { HCRO } & \text { HCRC } & \text { FFB } \\ \text { Apple "Red" } & \text { kg } & 19.18 & 9.89 & \\ \text { Banana "Prata" } & \mathrm{kg} & 13.58 & 4.99 & \\ \text { Beet root } & \mathrm{kg} & 16.38 & 2.89 & 5.00 \\ \text { Broccoli "Ninja" } & \mathrm{kg} & 10.39 & 4.90 & 6.90 \\ \text { Cabbage "Green" } & \mathrm{kg} & 5.29 & 3.89 & 3.90 \\ \text { Carrot } & \mathrm{kg} & 10.48 & 2.39 & 4.30 \\ \text { Collard "But er" } & \text { bunch } & 6.29 & 3.09 & 4.90 \\ \text { Grapes "Crimson" } & \mathrm{kg} & 15.18 & 15.18 & \\ \text { Grapes "Sugar One" } & \mathrm{kg} & 16.98 & 15.78 & \\ \text { Grapes "Red Globe" } & \mathrm{kg} & 17.98 & 13.78 & \\ \text { Kiwi } & \mathrm{kg} & 7.48 & 18.89 & \\ \text { Lemon "Tahit I" } & \mathrm{kg} & 12.38 & 2.39 & \\ \text { Let tice "Crespa" } & \mathrm{unity} & 8.39 & 2 ; 39 & 3.00 \\ \text { Melon "Pele de Sapo" } & \mathrm{kg} & 10.99 & 6.87 & \\ \text { Orange "Pera" } & \mathrm{kg} & 5.29 & 2.49 & \\ \text { Papaya "Formosa" } & \mathrm{kg} & 6.99 & 3.89 & \\ \text { Parsley and green onion } & \text { bunch } & 3.99 & 2.89 & 3.00 \\ \text { Pumpkin "Kabotchá" } & \mathrm{kg} & 7.89 & 2.69 & 3.90 \\ \text { Watermelon "Fairfax" } & \mathrm{kg} & 2.19 & 2.19 & \\ \text { Zucchini } & \mathrm{kg} & 15.38 & 6.89 & 5.80\end{array}$

HCRO - Hipermercado Carrefour, supermarket, organic produce

HCRC - Hipermercado Carrefour, supermarket, convent inal produce

FFB - Feira Convencional do Jardim Flamboyant - convent bnal outdoor market

HCRO most expensive $=19 / 20=95.0 \%$

HCRC cheapest $\quad=17 / 20-85.0 \%$

FFB cheapest $\quad=1 / 9-11.1 \%$

In the outdoor market no fruits were sold 


\subsection{Taquaral (Table 3)}

In Taquaral district data collection was conducted at Supermercado Dalben and Feira Convencional do Taquaral (outdoor market). 24 produce were offered in all three options. $10(41.7 \%)$ out of 24 organic produce offered by Supermercado Dalben (SDBO) were the most expensive; $18(75.0 \%)$ out of 24 conventional produce of Supermercado Dalben (SDBC) were the cheapest.

A different trend from other supermarket is that in the Supermercado Dalben it was found $4(16.7 \%)$ out of 24 organic produce offered were sold with the lowest prices. These produce were the eggplant, bell pepper "Green", cabbage "Green" and cabbage "Red". In the Feira Convencional do Taquaral (FTQ) 14 out of 24 (58.3\%) of the produce were the most expensive.

Prices in Reais (Brazilian Currency)

It was found in Taquaral 119 produce, being 66 vegetables and 53 fruits.

\begin{tabular}{|c|c|c|c|c|}
\hline Fruit or vegetable & Unity & SDBO & SDBC & FTQ \\
\hline African eggplant & kg & 5,49 & 6,99 & 8,00 \\
\hline Banana "Chunkey" & $\mathrm{kg}$ & 11,38 & 4,99 & 5,90 \\
\hline Beet root & kg & 6,59 & 2,99 & 10,00 \\
\hline Bell pepper "Green" & kg & 6,59 & 6,99 & 8,00 \\
\hline Broccoli "Ramoso" & bunch & 4,99 & 4,99 & 6,00 \\
\hline Cabbage "Green" & $\mathrm{kg}$ & 4,89 & 4,99 & 6,90 \\
\hline Cabbage "Red" & $\mathrm{kg}$ & 5,69 & 6,99 & 7,80 \\
\hline Cauliflower & unity & 7,99 & 3,90 & 7,80 \\
\hline Chayote & $\mathrm{kg}$ & 6,59 & 2,99 & 5,80 \\
\hline Collard "Butter" & bunch & 4,89 & 3,49 & 4,90 \\
\hline Eggplant & kg & 6,69 & 4,99 & 8,90 \\
\hline Green onion "Hosonegui" & bunch & 3,29 & 2,49 & 3,50 \\
\hline Lettuce "Green Leaf" & unity & 3,99 & 2,49 & 3,90 \\
\hline Lettuce "Lisa" & unity & 5,99 & 2,49 & 3,90 \\
\hline Lettuce "Red Leaf" & unity & 3,99 & 2,49 & 3,90 \\
\hline Parsley "Lisa" & bunch & 3,49 & 2,49 & 3,50 \\
\hline Parsley and green onion & bunch & 3,49 & 2,49 & 3,50 \\
\hline Potato & $\mathrm{kg}$ & 7,90 & 2,99 & 2,90 \\
\hline Pumpkin "Brasileira Green" & $\mathrm{kg}$ & 6,99 & 5,99 & 7,90 \\
\hline Pumpkin "Kabotchá" & kg & 6,79 & 3,49 & 5,80 \\
\hline Strawberry & kg & 31,56 & 16,63 & 16,50 \\
\hline Tomato "Italian" & kg & 7,79 & 3,99 & 7,80 \\
\hline Yam & kg & 7,99 & 4,90 & 8,70 \\
\hline Zucchini & $\mathrm{kg}$ & 11,32 & 5,99 & 6,90 \\
\hline $\begin{array}{l}\text { SDBO - Supermercado Dalbe } \\
\text { SDBC - Supermcercado Dalbe } \\
\text { FTQ - Feira convencional do }\end{array}$ & $\begin{array}{l}\text { organic } \\
\text {, convent } \\
\text { aquaral }\end{array}$ & $\begin{array}{l}\text { roducts } \\
\text { onal pro }\end{array}$ & & \\
\hline \multicolumn{5}{|c|}{ SBDO most expensive = 10/24 = 41,7\% } \\
\hline \multicolumn{5}{|c|}{ FTQ most expensive $=14 / 24=58,3 \%$} \\
\hline SBDC cheaoest & $=75,0 \%$ & & & \\
\hline SBDO cheapest & $=16,7 \%$ & & & \\
\hline
\end{tabular}




\subsection{Barão Geraldo (Table 4)}

In Barão Geraldo district data collection was conducted at Supermercado Pão de Açúcar of Barão Geraldo, at the Feira Orgânica de Barão Geraldo (organic outdoor market) and Feira Convencional de Barão Geraldo (conventional outdoor market).

19 produce were offered in all four options. All the 19 organic produce sold at Supermercado Pão de Açúcar (SPAOBG) were the most expensive.

13 out of $19(68.4 \%)$ of the conventional produce sold at the Supermercado Pão de Açúcar of Barão Geraldo (SPACBG) were the cheapest.

With respect to outdoor markets of this district 11 out of $19(57.9 \%)$ of the conventional produce were the most expensive.

At organic outdoor market (FOBG) $37.6 \%$ (6 produce out of 19) were the cheapest.

Prices in Reais (Brazilian Currency) Table 4. Produces (vegetables and fruits) sold at one supermarket and two
outdoor markets in Barão Geraldo, Campinas, Brazil

$\begin{array}{llllll}\text { Produce } & \text { Unity } & \text { SPAOBG } & \text { SPACBG } & \text { FOBG } & \text { FCBG } \\ \text { Avocado } & & & & & \\ \text { Banana "nanica" } & \mathrm{kg} & 14.48 & 6.99 & 8.00 & 8.90 \\ \text { Banana "prata" } & \mathrm{kg} & 11.65 & 4.49 & 5.50 & 5.90 \\ \text { Beet root } & \mathrm{kg} & 14.48 & 4.99 & 6.50 & 7.90 \\ \text { Carrot } & \mathrm{kg} & 14.82 & 2.59 & 6.00 & 7.80 \\ \text { Chayote } & \mathrm{kg} & 17.38 & 2.59 & 5.00 & 3.80 \\ \text { Collard } & \text { bunch } & 6.19 & 5.39 & 3.00 & 4.80 \\ \text { Eggplant } & \mathrm{kg} & 15.65 & 5.99 & 8.00 & 7.80 \\ \text { Ginger } & \mathrm{kg} & 43.30 & 6.99 & 25.00 & 15.00 \\ \text { Green cabbage } & \mathrm{kg} & 23.63 & 4.35 & 3.00 & 4.80 \\ \text { Lemon "cravo" } & \mathrm{kg} & 15.73 & 6.49 & 7.00 & 8.00 \\ \text { Lettuce "crespa" } & \mathrm{unity} & 5.09 & 3.49 & 2.00 & 3.00 \\ \text { Lettuce "lisa" } & \mathrm{unity} & 5.69 & 3.49 & 2.00 & 3.00 \\ \text { Lettuce "mimosa" } & \mathrm{unity} & 5.09 & 3.09 & 2.00 & 3.00 \\ \text { Orange "pera" } & \mathrm{kg} & 8.48 & 2.79 & 5.00 & 3.49 \\ \text { Passion fruit } & \mathrm{kg} & 21.98 & 6.99 & 11.00 & 9.90 \\ \text { Sweet potato } & \mathrm{kg} & 9.59 & 3.75 & 7.00 & 7.80 \\ \text { Yam } & \mathrm{kg} & 8.39 & 5.29 & 8.00 & 7.80 \\ \text { Zucchini } & \mathrm{kg} & 15.82 & 3.59 & 8.00 & 7.80\end{array}$

SPAOBG - Supermercado Pão de Açúcar of Barão Geraldo, organic produce SPACBG - Supermercado Pão de Açúcar of Barão Geraldo, conventional produce FOBG - Organic outdoor market of Barão Geraldo

FCBG - Conventional outdoor market of Barão Geraldo

SPAOBG most expensive $-19 / 19=100 \%$

SPACBG cheapest - $\quad 13 / 19=68.4 \%$

FOBG cheaoest - $\quad 6 / 19=37.6 \%$

FCBG most expensive $\quad 11 / 19=57.9 \%$ 


\subsection{Price difference above $200 \%$ (Table 5)}

There are 35 comparison pairs where 31 pairs $(88.6 \%)$ refer to comparison of organic and conventional produce sold in the same supermarket; 3 pairs refer to comparison of organic produce sold in two different supermarkets and one pair to a comparison of organic produce sold in a supermarket and an outdoor market.

Price differences above $200 \%$ were found for apple, beetroot, carrot, cassava, chayote, cucumber, Ethiopian eggplant, ginger, green cabbage, lettuce, onion, passion fruit, potato, red cabbage, sweet potato, tomato and zucchini. Excluding ginger, the remaining produce all vegetables and fruits of popular consumption.

Price differences above $500 \%$ (20\% of the comparison pairs) was found for organic and conventional chayote sold at Supermercado Pão de Açúcar of Cambuí (SPAOC/SPACC) which figure found was $733.2 \%$; for the same vegetable in organic and conventional version sold at Supermercado Pão de Açúcar of Barão Geraldo (SPAOBG/SPACBG) which figure was $571.0 \%$; for organic and conventional ginger sold at Supermercado Pão de Aççucar of Barão Geraldo (SPAOBG/SPACBG) which figure was $519.5 \%$; for organic green cabbage sold at Supermercado Pão de Açúcar of Barão Geraldo and at Organic Outdoor Market of Barão Geraldo (SPAOBG/FOBG) with the figure $687.7 \%$ and for organic and conventional zucchini sold at Hipermercado Carrefour (HCRO/HCRC) with the figure $530.8 \%$.

Price differences above $400 \%$ (17.1\% of the comparison pairs) were found for organic and conventional beetroot sold at Supermercado Pão de Açúcar of Cambuí (SPAOC/SPACC) with the figure $422.1 \%$; for the same vegetable in organic and conventional forms sold at the Hipermercado Carrefour (HCRO/HCRC) with the figure $466.8 \%$; for organic and conventional green cabbage sold at Supermercado Pão de Açúcar of Barão Geraldo (SPAOBG/SPACBG) with the figure $443.2 \%$; for organic and conventional sweet potato sold at Hipermcercado Carrefour (HCRO/HCRC) with the figure $401.3 \%$; for organic and conventional lemon Tahiti sold at Hipermercado Carrefour (HCRO/HCRC) with the figure $418.0 \%$ and for organic and conventional tomato "Salada" sold at Hipermercado Carrefour (HCRO/HCRC) with the figure 469.7 $\%$.

Price differences above $300 \%$ (20\% of the comparison pairs) are still large and not affordable for low income consumers.

Among 21 produce, there are 17 vegetables and only 4 fruits. 
Table 5. Produce price differences above $200 \%$

\begin{tabular}{|c|c|c|c|}
\hline Produce & Comparison & Difference & Local of commercialization \\
\hline Apple "Red" & HCRO/HCRC & $225.6 \%$ & Same supermarket \\
\hline Apple "Gala" & SPAOC/SPACC & $287.0 \%$ & Same supermarket \\
\hline \multirow[t]{2}{*}{ Beet root } & SPAOC/SPACC & $422.1 \%$ & Same supermarket \\
\hline & HCRO/HCRC & $466.8 \%$ & Same supermarket \\
\hline \multirow[t]{2}{*}{ Carrot } & SPAOC/SPACC & $218.6 \%$ & Same supermarket \\
\hline & HCRO/HCRC & $338.5 \%$ & Same supermarket \\
\hline Cassava & HCRO/HCRC & $322.8 \%$ & Same supermarket \\
\hline \multirow[t]{3}{*}{ Chayote } & SPAOC/SPACC & $733.2 \%$ & Same supermarket \\
\hline & SPAOBG/SPACBG & $571.0 \%$ & Same supermarket \\
\hline & HCRO/HCRC & $284.7 \%$ & Same supermarket \\
\hline Cucumber "japonês" & HCRO/HCRC & $214.1 \%$ & Same supermarket \\
\hline \multirow[t]{2}{*}{ Ethiopian eggplant } & SPAOC/SDBO & $234.8 \%$ & Both supermarkets \\
\hline & HCRO/SDBO & $234.8 \%$ & Both supermarkets \\
\hline Ginger & SPAOBG/SPACBG & $519.5 \%$ & Same suopermarket \\
\hline \multirow[t]{3}{*}{ Green cabbage } & SPAOBG/SPACBG & $443.2 \%$ & Same supermarket \\
\hline & SPAOBG/FOBG & $687.7 \%$ & Superm./outdoor market \\
\hline & SPAOC/SPACC & $549.6 \%$ & Same supermarket \\
\hline Lettuce "crespa" & HCRO/HCRC & $251.0 \%$ & Same suoermarket \\
\hline Lettuce "mimosa" & HCRO/HCRC & $204.2 \%$ & Same supermarket \\
\hline Lemon "Tahiti" & HCRO/HCRC & $418.0 \%$ & Same supermarket \\
\hline \multirow[t]{2}{*}{ Onion } & HCRO/HCRC & $228.5 \%$ & Same supermarket \\
\hline & SPAOC/SPACC & $297.3 \%$ & Same supermarket \\
\hline Orange & SPAOC/HCRO & $236.1 \%$ & Both supermarkets \\
\hline Passion fruit & SPAOBG/SPACBG & $214.4 \%$ & Same supermarket \\
\hline Potato & SPAOBG/SPACBG & $340.7 \%$ & Same supermarket \\
\hline \multirow[t]{2}{*}{ Red cabbage } & SPAOBG/SPACBG & $326.8 \%$ & Same supermarket \\
\hline & SPAOC/SPACC & $596.1 \%$ & Same supermarket \\
\hline \multirow[t]{3}{*}{ Sweet potato "Pink" } & HCRO/HCRC & $401.3 \%$ & Same supermarket \\
\hline & SPAOBG/SPACBG & $330.1 \%$ & Same supermarket \\
\hline & SPAOC/SPACC & $224.8 \%$ & Same supermarket \\
\hline
\end{tabular}




$\begin{array}{llll}\text { Produce } & \text { Comparison } & \text { Difference } & \text { Local of commercialization } \\ \text { Tomato "Salada" } & \text { HCRO/HCRC } & 469.7 \% & \text { Same supermarket } \\ \text { Tomato "Italiano" } & \text { HCRO/HCRC } & 217.6 \% & \text { Same supermarket } \\ & & & \\ \text { Zucchini } & \text { SPAOC/SPACC } & 385.7 \% & \text { Same supermarket } \\ & \text { SPAOBG/SPACBG } & 340.7 \% & \text { Same supermarket } \\ & \text { HCRO/HCRC } & 530.8 \% & \text { Same supermarket }\end{array}$

SPAOC - Supermercado Pão de Açúcar of Cambuí, organic produce SPACC - Supermercado Pão de Açúcar of Cambuí, conventional produce SPAOBG - Supermercado Pão de Açúcar of Barão Geraldo, organic produce SPACBG - Supermercado Pão de Açúcar of Barão Geraldo, conventional produce HCRO - Hipermercado Carrefour, organic produce HCRC - Hipermercado Carrefour, conventional produce SDBO - Supermercado Dalben, organic produce FOBG - Feira Orgânica do Barão Geraldo

\section{Discussion}

This research confirms part of the popular myth in Brazil that organic products are more expensive than conventional ones in supermarkets.

In the Supermercado Pão de Açúcar located in Cambuí 78.6 \% (11 out 0f 14) of organic produce were the most expensive (Table 1); in the Hipermercado Carrefour located in Jardim Flamboyant, $95.0 \%$ (19 out of 20) of the organic produce are most expensive (Table 2); in the Supermercado Dalben located in Taquaral neighborhood 41.7\% (10 out of 24) organic produce (SDBO) are the most expensive (Table 3); in the Supermercdo Pão de Açúcar of Barão Geraldo (SPAOBG) $100 \%$ of the organic produce are the most expensive (Table 4).

Different trend is observed in Taquaral where $58.3 \%$ (14 out of 24) of the conventional produce offered by the Feira Covencional do Taquaral (FTQ) were the most expensive.

For conventional produce sold in supermarkets $71.4 \%$ (10 out of 14) of the conventional produce sold in Supermercado Pão de Açúcar of Cambuí (SPACC) were the cheapest (Table 1) in Hipermercado Carrefour (HCRC) this figure was $85.0 \%$ (17 out of 20) (Table 2); in Supermercado Dalben (SDBC) the figure was $75.0 \%$ (18 out of 24) (Table 3); in Supermercado Pão de Açúcar of Barão Geraldo the figure was $68.4 \%$ (13 out of 19) (Table 4).

The selected supermarkets establish a business strategy whereby they sell organic products at a higher cost to consumers who can pay or agree to pay the highest and cheapest prices. In general, consumers who prefer cheaper products buy conventional supermarket products and part of this purchasing universe is low-income customers.

This is the conclusion after analyzing the results of Tables 1 to 4. Cambuí is a neighborhood where upper-middle-class people live, for whom the Pão de Açúcar 
Supermarket is offering its organic products at high prices $(78.6 \%)$. This supermarket is offering conventional products at low prices $(71.4 \%)$ to consumers in general and low income consumers who eventually visit this supermarket. Low-income customers are workers (domestic servants, commercial services) who work in the neighborhood, but generally live far from Cambuí, in remote neighborhoods of Campinas.

In Jaguariúna, about $25 \mathrm{~km}$ from Campinas, there is a production unit of $130 \mathrm{ha}$, called Vila Yamaguishi. The Yamaguishi farm produce a diverse range of fruit and vegetables and high quality organic fruits. Yamaguishi Farm maintains a large stand at the Organic Fair of Cambuí (FPE) offering its high quality organic products. This foreign market is open on Sundays, which facilitates the access of customers. On other days of the week, Yamaguishi Farm maintains small stands selling the same organic products in the neighborhoods of Campinas do Jardim Guanabara, Bosque dos Jequitibás and Cambuí (the same neighborhood of Yamaguishi Farm).

This is the stand of Sunday, established in the Ecological Park, but in a different place, in the Coexistence Center. (Centro de Convivência).

Flamboyant Garden is a middle-class neighborhood, but the Carrefour Hypermarket, where it is located, is visited by high-income people for whom this supermarket offers organic produce at high prices $(95.0 \%)$. As in the case of Pão de Açúcar Supermarket, Carrefour Hypermarket is offering cheap conventional products accessible to lowincome people $(85.0 \%)$ (Table 2$)$.

Taquaral is a middle class neighborhood where the Dalben Supermarket is located. In this supermarket only $41.7 \%$ of organic products are the most expensive. To serve lowincome customers, Dalben offers $75.0 \%$ of its conventional products at cheaper prices (table 3).

The Barão Geraldo district is located near the State University of Campinas (UNICAMP) and is inhabited by upper middle class people. Barão Geraldo's Pão de Açúcar Supermarket (SPAOBG) is selling organic products at high prices, but there are also conventional low-priced products for low-income customers.

It is important not only just the statement of the prices differences, but to study the magnitude of these differences between organic and conventional produce.

While the differences in the interval $0<\% \leq 100$ are still acceptable and affordable for low economic class customers, differences in the higher interval of $100<\% \leq 200$ have already deeper impact on the customers, differences above $200 \%$ have still deeper effect on the customers, it even can affect the high middle class when they are making decision whether to buy or no a specific item sold for very high price of more than 200 $\%$ expensive. Price differences above $300 \%$ is difficult to be afforded even by the wealthy customers.

The very high difference of $733.2 \%$ of chayote price at Supermercado Pão de Açúcar of Cambuí (SPAOC/SPACC) can be explained by the very low price of conventional chayote of R1.99/kg when compared to acceptable price of organic chayote of $\mathrm{R} \$ 16.58 / \mathrm{kg}$. 
According to Table 5, the largest differences in prices of organic and conventional produce are within the same supermarkets $(88.6 \%$ of the comparison pairs or 31 pairs out of 35).

Comparisons between the organic produce sold at different supermarkets did not conducted to high values: In the comparison Supermercado Pão de Açúcar of Cambuí/Hipermercado Carrefour (SPAOC/HCRO) no one organic produce price difference exceeded $100 \%$; in the comparison Supermercado Pão de Açúcar of Cambuí/Supermercado Dalben (SPAOC/SDBO) only the difference in the prices of Ethiopian eggplant exceeded $200 \%$, being the figure $234.8 \%$. Close to this value was the bell pepper "Green" prices difference, the figure being 197.1\%. In the comparison Hipermercado Carrefour/Supermercado Dalben (HCRO/SDBO) again the organic Ethiopian eggplant price difference exceeded $200 \%$, the figure being also $234.8 \%$ (Table 5).

The comparison between the Pão de Açúcar de Cambuí Supermarket and the Parque Ecológico Organic Fair (SPAOC/FPE). The price of organic onions offered by the foreign market was $320.2 \%$ higher than the same product sold by the Pão de Açúcar supermarket. The other price differences did not exceed $200 \%$. In the Carrefour Hypermarket/Organic Fair of the Ecological Park (HCRO/FPE) comparison, no difference exceeded $200 \%$. This comparison also did not lead to high price differences, except for the onion marketed by Feira do Parque Ecológico (FPE).

Excluding onions, all organic prices in supermarkets (SPAOC and HCRO) were higher than in the organic market (FPE).

Conventional produce prices comparisons between supermarkets and outdoor markets It was stated in the research that the conventional produce present lower prices in supermarkets than in outdoor markets. Even so, it is preferable for the low income consumers seek conventional produce at outdoor markets because are fresher and healthier than those of supermarkets. Produce sold in supermarkets travel long distance from the production places and the selling points. Almost all the Campinas districts are served by outdoor markets, therefore there is no problem with respect to distance between the owners' residences and the outdoor markets.

Organic produce prices comparisons between supermarkets and outdoor markets According to the research statement, the organic produce' prices are lower at outdoor markets than at supermarkets, are also fresher, healthier because are produced near the selling points (less than $200 \mathrm{~km}$ ). Thus, the low income consumers have to their disposal organic produce sold for lower prices at organic outdoor markets than at supermarkets. Yet the low income consumers can choose among the organic produce sold at the outdoor markets, the "in season" produce which present superior nutritional quality when compared to "out of season" produce and are sold for prices still lower because of their higher offer during the season.

Presently there are 5 organic outdoor markets in Campinas, which are located in Cambuí, Barão Geraldo (Watanabe et al., 2018), Jardim Guanabara, Parque Ecológico and Bosque dos Jequitibás. The organic outdoor market of Parque Ecológico is easily reached and is held on Sundays, what facilitates the low income consumers access. This organic produce selling point is visited by consumers belonging to all socio-economic 
classes, inhabiting all Campinas districts. The Fazendas Yamaguishi (https://www.yamaguishi.com.br) which produce high quality organic produce, keep stands in Cambuí, Jardim Guanabara, Parque Ecológico and Bosque dos Jequitibás.

Contribution of organic outdoor markets to economic development - Several studies point out to the economic and social importance of the organic agriculture in Brazil, specially with the combinations of the different vending channels (Oelopse et al., 2010; Sposito and Abreu, 2017; Darolt et al., 2014 and Gelying et al., 2013).

Returning to the central question of this research, i.e. to assess whether the organic fruits and vegetables produced are more expensive than conventional products, it is concluded that fresh, healthy, seasonal organic products, sold at affordable prices to low-income customers. Economical, ecological and social reasons for this choice should be explained. The scenarios are potentially promising for the development of the organic agriculture and its relation with different markets of São Paulo and of Brazil where the outdoor markets are recognized as suitable arrangements for the smallholder farmers to commercialized their produce locally, once it promotes the amplification of the direct sales from producers to urban consumers. The organic outdoor markets are also a space for social solidarity for small farmers who also have an opportunity to approximate with the consumers. Many of these producers are threatened by social exclusion, specially those who are established near large metropolis, where the rural environment is strongly valorized by real state speculation.

This research contributes for the understanding that the sales at outdoor markets offer a higher set of opportunities for the producer such as: higher profit margin, diversification of the production, sale guarantee, risk reduction, autonomy and financial independence. The study also present the potential for the combination of different sale channels. The security and guarantee of production sale and the possibility to establish direct relation between the producer and the consumer without doubt enable the social valorization and autonomy of the organic producers.

By buying organic products on the foreign market, consumers are contributing to the generation of income for family farmers and the rural exodus is discouraged. This is the benefit of establishing the foreign market in the community for small farmers (Camarando and Abramovay, 1999; Ferrari et al., 2004; Castro, 2004).

The establishment of a farmer organic outdoor market in a district benefits the community specially the low income community, providing its food security, contributing to agricultural diversity and keeping the environment ecologically clean (Jolly et al., 2005). Provided that:

1. The intake of fruit and vegetables below the WHO/FAO recommendation of $400 \mathrm{~g}$ or 5 daily doses occurs among low-income people, this occurs in the city of São Paulo, Brazil (Viebig et al., 2009);

2. Organic fruit and vegetables are healthier than conventional (AAO, s. d.; Guivant, 2003.; Noronha, 2008; Vicente et al., 2009; Dunn et al., 2014; Johansson et al., 2014)

3. The supermarket organic produce are more expensive than in the organic produce of the outdoor markets (Souza, 2005; Watanabe et al., 2018) 
4. Organic produce sold at supermarkets are less fresh and less healthy because of the time elapsed between the harvest and commercialization, and because of the long distance between the production places to the supermarkets (Holloway and Kneafsey, 2000; Sanderson et al., 2005; Souza, 2005; Potrich et al., 2013)

5. Supermarkets offer at low prices only conventional products (Watanabe et al., 2018) that are at risk of being contaminated by chemical residues (Noronha, 2008. Smith Spangler et al., 2012; Dunn et al., 2014) and heavy metals (Woese et al., 1997; Mansur et al., 2009).

To attend low-income people seeking fresh organic produce the City Hall Government should create new organic outdoor markets, distributed in several peripheral districts of Campinas. Certainly, there is no shortage of organic farmers interested in commercializing their organic produce in outdoor markets.

The low income people best choices when organic outdoor markets are not available near their residences, is to rely on conventional produce sold at outdoor markets because the produce sold at these markets are fresher than the conventional produce sold at the supermarkets.

The owner of the stands grow the produce sold in outdoor markets because they are the fruit and vegetable producers. Whereas the organic produce sold in the supermarkets besides being more expensive, they have to travel long distance from producing places to the supermarkets, passing through a chain of intermediaries. Then the costs of commercialization of produce in the supermarkets becomes high. Pingali et al. (2005) enlisted several ways by which the cost of agricultural produce grown by smallholder farmers can be reduced. The outdoor market stand owners because they are also the producers of the products can offer them for cheaper prices than the supermarkets. Travelling for shorter distances, the organic produce offered in the outdoor markets reach the consumer's hands fresher and within shorter time after harvest. Renting et al. (2003), Goodman and Goodman (2009), Coley et al. (2009), Akkerman et al. (2010), Van Passels (2010), and Maye and Kirvan (2010) discussed the effect on the quality and prices of the distance the food travels until reaches the consumers. The longer the travel the lower the quality and the higher the price of the food. This can be solved by adoption of Alternative Food Networks (AFN) which shorten the distance and time between food production and consumption (Renting et al. 2003; Pingali et al., 2005; Goodman and Goodman, 2009). In summary, purchasing organic produce at the outdoor markets the low income consumers can get fresher and healthier produce for affordable prices.

Purchasing horticultural produce from the outdoor markets the customers contribute for the economic development and survival of smallholder farmers, help to maintain these farmers on their lands. All of these parameters are important social role performed by the customers who purchase organic produce from the outdoor markets owners, who are also farmers who produce the horticultural products sold at their stands (Jolly et al., 2005). The Brazilian organic horticultural production were reported by Moreira (2006), Lucena et al. (2010), Pádua (2014) and Kronbauer et al. (2018).

A paper by USAID (2005) and WHO/FAO (2004) report the organic horticulture products problems production and distribution in all world continents. 


\section{Conclusions}

One of the contributions of the research was that of our discovery that at the supermarkets the organic produce prices are in fact higher than that of the conventional, confirming the myth/fallacy according to which organic produce are always more expensive than the conventional produce. At the outdoor market on the other hand, many of the organic produce present prices even lower or equal to the conventional, what contradicts the myth or fallacy. As still exist some organic produce being sold at outdoor markets for higher prices than that of the conventional, it cannot generalize such a way to refute entirely the myth/fallacy in relation to produce commercialized in outdoor markets.

Through this research were defined four strategies for purchase of produce in Campinas metropolitan region, which were recommended to low income consumers, which are subsidy for the establishment of a program of alimentary education:

a. Give preference to organic produce as they are pesticide contamination-free

b. Purchase organic produce at outdoor markets because they are fresher as they are produced in the proximities of the outdoor markets (distance between the farms and the outdoor markets less than $200 \mathrm{~km}$ ).

c. Among the stand owners, choose who are also farmers, who are selling in the stands their own organic harvests, directly to the consumers, who then have the opportunity to know the producers of the produce which are purchasing

d. Among the organic produce sold by the own producers, choose those that are "in season", as they have superior nutritional quality and also are sold for lower prices than produce "out of season"; "in season" produce are cheaper because their offer are higher during their season. As different products peak their harvest at different times of the year, consumers are able to have a diversified diet throughout the year, which is an even healthier eating habit.

\section{References}

AAO - Associação de Agricultura Orgânica, s. d.

Akbaba, U.; Sahin, Y.; Tukez, H. 2012. Comparison of Element Contents in Haricot Beans Grown under Organic and Conventional Farming Regimes for Human Nutrition and Health Acta Scientiarum Polonorum Hortorum Cultus 11(2): 117125.

Akkerman, R.; Farahani, P.; Grunow, M. 2010 Quality Safety and Sustainability in Food Distribution: A Review of Quantitative Operations Management Approaches and Challenges. OR Spectrum, 32 (4): 863-904.

Ali, M. and Farooq, O. 2004. Dietary Diversity and Rural Labor Productivity: Evidence from Pakistan. Long Paper no. 116.971. American Economic Association Annual Meeting. 37 pp.

Arbos, K. A.; de Freitas, R. I. S.; Stetz, S. C.; Domas, M. F. 2010. Antioxidant Activity and Phenolic Contents in Organic and Conventional Vegetables. Cienc. Technol. Aliment., 30: 501-506.

Archer, G. F. 2003. Latent Consumers' Attitude to Farmers' Markets in North West England. British Food Journal, 105 (8): 487-497. 
Bigaran, J. T. and Salgado J. M. 2017. Consumo de Frutas e Hortaliças "in Natura" no Município de Piracicaba/SP e sua Implicação no Estado Nutricional: Uma Abordagem Sócio-econômica. Revista Espacios, 38 (9): 10 pp.

Camarando, A. A. and Abramovay, R. 1999. Exxodo Rural, Envelhecimento e Masculinização no Brasil, Panorama dos Últimos 50 Anos. Desafios do Desenvolvimento IPEA, Texto para Discussão no. 621, 28 pp.

Cardoso, P. C.; Tomazino, A. P. B.; Stringheta, P. C.; Ribeiro, S. M. R.; Pinheiro, Sant'Ana, H. M. 2011 Food Chem. 126: 411-416.

Carys-Veyrat, C.; Amiot,M. J.; Tyssandier, V.; Grasselly, D.; Buret, M.; Mikoljtzak, M.; Guland, J. C.; Boutgelof-Demange, C.; Borel, P. 2004. Influence of Organic vs Conventional Agricultural Practice on the Antioxidant Microconstituent Content of Tomatoes and Derived purees: Consequences on Antioxidant Plasma Status in Humans. J. Agr. Food Chem. 52: 6503-6509.

Castro, E. G. 2005. Entre Ficar e Sair: Uma Etnografia da Construção Social da Categoria Jovem Rural. Unpublished Doctoral Thesis, Universidade Federal do Rio de Janeiro, Rio de Janeiro, RJ, Brazi. 444pp.

CEAGESP s. d.

Cogill, B. 2015. Contributions of Indigenous Vegetables and Fruits to Dietary Diversity and Quality. Acta Horticulturae, 1102: 213-228.

Colla, C. 2008. Principais Motivos para Consumidores de Cascavel e Toledo (PR) Buscarem as Feiras Livres são a Qualidade e o Frescor dos FLV.

Colla, C. 2008. Análise do Comportamento do Consumidor das Feiras-livres nos Municípios de Cascavel e de Toledo, PR. Unpublished Master Dissertation. Universidade Estadual do Oeste do Paraná, Brazil. 128 pp.

Coley, D.; Howard, M.; Winter, M. 2009. Local Food, Food Miles and Carbon Emissions: A Comparison of Farm Shop and Mass Distribution Approaches. Guilford, United Kingdom, Food Policy, 34: 150-155.

Darolt, M. R.; Lamine, C.; Alencar, R. M. de C. F.; Abreu, L. S. de. 2015. Redes alimentares alternativas e novas relações produção-consumo na França e no Brasil. In: Brandenburg, A.; Billaud, J. P.; Lamine, C. Redes de Agroecologias: Experiências no Brasil e na França. Curitiba, PR, Brazil, Queirós Edições, p. 111133.

Dunn, J.; Pawlewicz, A.; Rorawski, P. 2014. Development of Organic Farming in the USA Oeconomia, 13 (3): 55-68.

FAO - Food and Agriculture Organization of the United Nations 2015. Promotion of Fruit and Vegetables for Health. Report of the Pacific Regional Workshop, Rome, Italy. 94 pp.

Ferrari, D. L.; Abramovay, R.; Silvestro, M. L.; Mello, M. A. de; Testa, V. M. 2004. Dilema e Estratégia dos Jovens Rurais: Ficar ou Partir ? Estudos Sociedade e Agricultura, 12 (2): 237-271.

Gautier, H.; Diakou-Verdin, V.; Bernard, G.; Reich, M.; Buret, M.; Boureaud, R.; Poessel, J. L.; Carys-Veyrat, C.; Genard, M. 2008. How does Tomato Quality (Sugar, Acid and Nutritional Quality) Vary with Ripening Stage, Temperature and Irradiation? J. Agric. Food Chem., 56: 1241-1250.

Gelying, H.; Abreu, L. S. de; Li, L.; Fonseca, M. F. 2013. Comparative instituticonal analyses of certified organic agriculture conditions in Brazil and China. In: 
Halberg, N.; Muller, A. (eds.) Organic Agriculture for Sustainable Livelyhoods. Routlege, pp. 204-222.

Goodman, D. and Goodman, M. 2009. Alternative Food Networks. In: Kitchin, R. and Thrift, M. (eds.) International Encyclopedia of Human Geography, Boston, USA, pp. 208-220.

Guivant, J. C. S. 2003. Os Supermercados na Oferta de Alimentos Orgânicos: Apelando ao Estilo de Vida Ego-trip. Ambiente e Sociedade, 6 (2): 63-81.

Guthrie, J.; Guthrie, A.; Lawson, R.; Cameron, A. 2006. The Small Business Counter Revolution in Food Production and Retailing. British Food Journal 108 (7): 560573.

Hall, J. N.; Moore, S.; Harper, S. B.; Lynch, J. W. 2009. Global Variability in Fruit and Vegetable Consumption. Am. J. Preventive Medicine, 36 (6): 402-409.

Halllmann, E.; Rembialkowska, E. 2012. Characterization of Antioxidant Compounds in a Sweet Bell Pepper (Capsicum annuum, L.) under Organic and Conventional Growing Systems. J. Sci. Food Agr. , 92: 2409-2415.

Holloway, L.; Kneafsey, M. 2000. Reading in Space of the Farmers' Market: A Preliminary Investigation from the UK. Sociologia Ruralis 40 (3): 285-299.

IBGE - Instituto Brasileiro de Geografia e Estatística. 2006. Censo Agropecuário. 775 pp.

Johansson, E.; Hussain, A.; Kuktaite, R.; Andersson, S. S.; Olsson, M. E. 2014. Contribution of Organically Grown Crops to Human Health. Int. J. Environ. Res. Public Health 11: 3870-3893.

Jolly, D.; Eckert, E.; Ashworth, S. 2005. The Farmers Market Management Series Vol. 1, University of California Small Farm Center, Davis, California, USA. 108 pp.

Kader, A. A.; Perkins, P.; Lester, G. 2014. Nutritional Quality of Fruits, Nuts and Vegetables and their Importance in Human Health. 8 pp.

Kloppenburg Jr., J.; Hendrickson, J.; Stevenson, G. W. 1996. Coming in to the Foodshed. Agriculture and Human Values, 13 (3): 33-42.

Kronbauer, E. A.; Kolochinski, E. M.; Sant'Anna, V.; Biondo, E. 2018. Manejo Orgânico e Valorização de Produto Agrícolas Locais: Reflexão sobre a Produção de Alimentos Orgânicos no Município de Arroio do Meio - RS. Revista Científica Rural, 20 (1): 129-150.

Lucena, R. M. de; Campeão, P.; Tomas, R. N.; Oliveira, T. G.; Chaebo, G. 2010. Agricultura Familiar e Produção Orgânica: Elementos Morfológicos e Constitutivos de uma Rede Horizontal Formada em Campo Grande - MS. 48th SOBER Sociedade Brasileira de Economia, Administração e Sociologia Rural 14 pp.

Mac Diamid, J. I. 2014. Seasonality and Dietary Requirements: Will Eating Seasonal Food Contribute to Health and Environmental Sustainability? Proc. Nutr. Soc. 73 (3): 368-375.

Mansur, S. A.; Belal, M. H.; Abou-Arab, A. A. K.; Asbour, M. M.; Gad, M. F. 2009. Evaluation of Some Pollutant Levels in Conventionally and Organically Farmed Potato Tubers and their Risks to Human Health, Food Chem, Toxicol. 47: 613624.

Maye, D. and Kirwan, J. 2010. Alternative Food Networks. Sociopedia ISA International Sociological Association. 12 pp. 
Ministério da Saúde 2009. Ações de Incentivo ao Consumo de Frutas e Hortaliças do Governo Brasileiro. $12 \mathrm{pp}$.

Moreira, C. A. 2006. Produção e Mercado de Frutas, Legumes e Verduras Orgânicas na Região de Influência Econômica de Goiânia - GO.. Unpublished Master Dissertation. Universidade Federal de Goiás, Goiânia, Brazil. 146 pp.

Morel, A. P. S.; Rezende, L T.; Tannure, P. T.; Ferreira, C. de A.; Sette, R. de S. 2015. Comportamento do Consumidor das Feiras-livres: Um Estudo em um Município de Minas Gerais. Teresina, Revista FSA, 12 (4): jul-aug 2015.

Noronha, I. de O. 2008. O Comportamento do Consumidor das Feiras de Produtos Orgânicos de Belo Horizonte, Minas Gerais. Unpublished Master Dissertation. Fundação Cultural Dr. Pedro Leopoldo, Belo Horizonte, Brazil. 107 pp.

Oleofse, M.; Hogh-Jensen, H.; Abreu, L. S. de; Almeida, G. F. DE; Hui, Q. Y.; Sultan, T.; Neergaard, A. de 2010. Certified organic agriculture in China and Brazil: Market accessibilityu and outcomes following adoption. Ecological Economics,69(9):1785-1793, ISSN: 0921-8009, doi: 10.1016/j.ecolecon. 2010.04.016

Pádua, J. B. 2014. Produção e Comercialização de Produtos Orgânicos pela Agricultura Familiar em Mato Grosso do Sul. Unpublished Master Dissertation, Dourados, MS, Brazil. 83 pp.

Pereira, V. E.; Moreira, A. B. S.; Pagotto, A.; Zanluchi, C. E.; Amadei, C.; Beppu, C. Y.; Ferraz, M. M.; Viviani, R.; Theodoro, R. R. S.; Maia, R. S. D.; Sazonalidade dos Alimentos, Governo do Estado de São Paulo, Secretaria da Fazenda, 5 pp.

Pingali, P.; Khwaja Y.; Melier, M. 2005. Commercializing Small Farms: Reducing Transaction Costs. FAO Food and Agriculture Organization, ESA Working Paper no. 03-08, 39 pp.

Potrich, A. C. G.; Pinheiro, R. R.; Schmidt, D. 2013. Estudo Comportamental de Aquisição e Consumo de Frutas, Legumes e Verduras na Região Central e Médio Alto Uruguai. Goiânia, Enciclopedia Biosfera 9 (17): 34-74.

Renting, M.; Marsden, T.; Banks, J. 2003. Understanding Alternative Food Networks: Exploring the Role of Short Food Supply Chain in Rural Development. Environment and Planning 35: 303-411.

Rimm, E. R.; Ascherio, A.; Giovannucci, E.; Spregelman, D.; Stampfer, J. J.; Willey, W. C. 1996. Vegetable, Fruit and Cereal Fiber Intake and Risk of Coronary Heart Disease Among Men. J. Am. Med. Assoc. 275: 447-45.

Sanderson, K.; Gertler, M.; Martz, D.; Mahabir, R. 2005. Farmers' Markets in North America: A Literature Review. University Institute for Social Research, Sakatoon, UIniversity of Saskatchevan, Canada. 33 pp.

Smith-Spangler, C.; Brandeau, M. I.; Hunter, G.; Clay-Bavinger, J.; Pearson, N.; Echbach, P. J.; Sundaram, V.; Liv. H.; Staue, C.; Olkin, IO.; Bravata, D. M. 2012. Are Organic Foods Safer or Healthier than Conventional Alternatives? A Systematic Review. Annal. Int. Med. 151: 348-366.

Souza, R. A. M. 2005. Mudanças no Consume e na Distribuição de Alimentos: O Caso da Distribuição de Hortaliças de Folhas na Cidade de São Paulo. Unpublished Master Dissertation Universidade Estadual de Campinas, Campinas, Brazil. 150 pp. 
Sposito, H.; Abreu, L. S. de; 2017. Diversidade da produção familiar e da comercialização de produtos orgânicos de Vitória (ES). Redes 22 (3): 292-315.

Stracke, B. A.; Ruefer, C. E.; Bub, A.; Brivibak, K.; Seifert, S.; Kunz C.; Watzl, B. Bioavailability and Nutritional Effect of Carotenoids from Organically and Conventionally Produced Carrot in Healthy Men. Brit. J. Nutr. 101: 1664-1672.

USDA - United States Department of Agriculture - Farmers Market Directory 2018, 40 pp.

USAID - University of California at Davis 2005.

Global Horticulture Assessment - International Program Office 144 pp.

Van Passels, S. 2010. Footmiles to Assess Sustainability: A Revision. International Society for Ecological Economics (ISEE) 12 ${ }^{\text {th }}$ Biennal Conference. Challenges and Contribution for a Green Economy. Rio de Janeiro, Brazil.

Vicente, A. R.; Manganans, G.; Sozzi, G. G.; Crisosto, C. H. 2007. Nutritional Quality of Fruits and Vegetables. Elsevier, Academic Press, Chapter 5, $51 \mathrm{pp}$.

Viebig, R. F.; Pastor-Valero, M.; Scazufca, M.; Menezes, P. R. 2009. Consumo de Frutas e Hortaliças por Idosos de Baixa Renda na Cidade de São Paulo. Revista Saúde Pública 43 (5): 806-813.

Watanabe, M. A.; Luiz, A. J. B.; Abreu, L. S. de 2018. Preços de Horti-frutis Convencionais e Orgânicas em Feiras-livres e Supermercados de Barão Geraldo, Campinas, SP, Brasil. 56th SOBER - Sociedade Brasileira de Economia, Administração e Sociologia Rural, 11 pp.

WHO/FAO - World Health Organization/Food and Agriculture Organization. 2004. Report of a Joint FAO/WHO Workshop. Kobe, Japan, 45 pp.

Woese, K.; Lange, D.; Boess, C.; Bogl, K. W. 2009. A Comparison of Organically and Conventionally Grown Foods: A Systematic Review. American J. Clin. Nutr. 90: 680-685.

Woese, K.; Lange, D.; Boess, C.; Bogl, K. W. 1997. A Comparison of Organically and Conventionally Grown Foods: Results of a Review of the Relevant Literature. $J$. Sci. Food Agr. 74: 281-293. 